\title{
Research on the Development of Science and Technology Innovation of Small and Medium Sized Enterprises in Liaoning
}

\author{
Chen Jiaqi \\ Bohai University \\ Jinzhou Liaoning, China
}

\begin{abstract}
Small and medium-sized science and technology enterprises play an important role in Liaoning's economy. Based on the investigation report of science and technology innovation small and medium-sized enterprises in Jinzhou, this article discussed basic situation, operation and existing problems of small and medium enterprises with technological innovation. In the end, the article proposed the countermeasures and suggestions for improving the innovative ability of technological innovation-oriented SMEs, such as strengthening the construction of collaborative innovation, improving the efficiency of scientific and technological innovation and implementing "innovation + " action plan to cultivate new economic growth points and to improve incentive mechanism and dynamic role of innovative talents, etc.
\end{abstract}

Keywords-Innovation; Small and medium-sized enterprises; Incentive mechanism of innovative

\section{INTRODUCTION}

Small and medium-sized science and technology enterprises play an important role in enhancing the ability of scientific and technological innovation, supporting sustainable economic development, and expanding social employment. Therefore, it is necessary to further rally the strength of all parties, cultivate and strengthen the scientific and technological SMEs, drive the scientific and technological SMEs to take the road of innovation and development, and provide important support for economic and social development. In 2017, we conducted in-depth research on 29 small and medium-sized enterprises with scientific and technological innovation identified in 2015 and 2016. The existing problems have a more comprehensive and in-depth understanding. The following are summarized as follows:

II. ANALYSIS OF THE BASIC SITUATION OF SMALL AND MEDIUM ENTERPRISES WITH TECHNOLOGICAL INNOVATION

\section{A. The nature of enterprise}

Among the small and medium-sized technological innovative enterprises, the vast majority are limited liability companies, with 26 enterprises accounting for $90.0 \%$ of the total number of enterprises; a small number are limited companies, with only 3 enterprises accounting for $10.0 \%$ of the total number of enterprises.

\section{B. Distribution of enterprises}

1) Geographical distribution

Small and medium-sized technological innovative enterprises are mainly distributed in high-tech zones (8 enterprises), Taihe District (7 enterprises), Yixian County (5 enterprises) and Linghai City (4 enterprises) in four counties (cities); in addition, they are scattered in Binhai New District (2 enterprises), Linghe District (1 enterprise), Guta District (1 enterprise) and Beizhen City (1 enterprise) in four districts (cities)

Most of the small and medium-sized technological innovative enterprises (SMEs) are concentrated in industrial parks (university science and technology parks, high-tech zones, Industrial Industrial zones), and 22 SMEs are located in industrial parks, accounting for $75.9 \%$ of the total enterprises.

\section{2) Distribution according to technology}

Among the small and medium-sized enterprises with scientific and technological innovation, they mainly focus on six technical fields, such as power electronics, equipment manufacturing, new materials, biomedicine, food and beverage, automotive parts and components. Among them, 11 are in the field of power electronics, accounting for $37.9 \%$; 6 are in the field of equipment manufacturing, accounting for $20.7 \%$; 4 are in the field of new materials, accounting for $13.8 \%$; 4 are in the field of biomedicine, accounting for $13.8 \% ; 3$ are in the field of food and beverage, accounting for $10.3 \%$; and 1 are in the field of automotive parts and components. Households account for $3.4 \%$ of the total number of enterprises.

\section{C. listing or expected listing of enterprises}

Among the 29 technological innovative SMEs, one enterprise (Liaoning Weisen Information Technology Co., Ltd.) is listed on the new third board, the parent company of one enterprise (Liaoxi Transformer Co., Ltd.) is listed on the new third board, and one enterprise is expected to be listed. Due to the constraints of their own conditions and other factors, the enterprises will not have strong intention to go public. 


\section{Enterprise personnel situation}

Among the 29 small and medium-sized enterprises with scientific and technological innovation, there were 4259 employees (1115 new employees) in the end of 2016. Among them, 1003 were technicians, accounting for $23.6 \%$ of the total number of employees; 1527 were college graduates or above, accounting for $35.9 \%$ of the total number of employees. The proportion of technical personnel and junior college students is significantly higher than that of other types of enterprises.

\section{THE OPERATION OF TECHNOLOGICAL INNOVATION SMALL AND MEDIUM-SIZED ENTERPRISES}

\section{A. Science and technology economic operation analysis}

Over the past three years, 29 small and medium-sized technological innovative enterprises have undergone continuous innovation and development, with rapid growth and sound economic performance.

\section{1) Annual output value}

In 2014, 2015 and 2016, the annual output value of 29 small and medium-sized science and technology innovation enterprises was 999.5 million yuan, 954.19 million yuan and 113.69 million yuan, respectively, with an average annual growth rate of $6.9 \%$. The annual output value of enterprises is faster than that of other types of enterprises.

\section{2) The income of new products}

In 2014, 2015 and 2016, 29 small and medium-sized science and technology innovation enterprises'new product income was 372.64 million yuan, 367.75 million yuan, 498.93 million yuan, with an average annual growth rate of $16.9 \%$. The new product income accounted for $37.3 \%, 38.5 \%$ and $49.9 \%$ of the annual sales revenue respectively. The new product income accounted for an increasing proportion of the annual sales revenue year by year. The proportion of new product income of all enterprises is higher than that of other types of enterprises.

\section{3) Net profit situation}

In 2014, 2015 and 2016, the net profits of 29 small and medium-sized technological innovation enterprises were 40.87 million yuan, 62.71 million yuan and 66.12 million yuan, respectively, with an average annual growth rate of $30.9 \%$. The net profit growth rate of enterprises is higher than that of other types of enterprises.

\section{4) Pay taxes and fees}

In 2014, 2015 and 2016, 29 small and medium-sized technological innovative enterprises created 61.62 million yuan, 69.12 million yuan and 81.46 million yuan respectively for the state, with an average annual growth rate of $16.1 \%$. The growth rate of taxes paid by enterprises is higher than that of other types of enterprises.

\section{B. Analysis of technological innovation}

\section{1) $R \& D$ institutions are sound}

Among the 29 small and medium-sized technological innovative enterprises, 4 provincial engineering and technical research centers have been approved, 11 municipal engineering and technical research centers have been set up, and 18 enterprises have set up R\&D institutes by themselves or jointly with research institutes of universities.

\section{2) $R \& D$ investment continues to increase}

In 2014, 2015 and 2016, the R\&D expenditures of 29 small and medium-sized technological innovative enterprises were 94.79 million yuan, 108.92 million yuan and 11.21 million yuan, respectively. The R\&D investment accounted for $9.5 \%$, $11.4 \%$ and $10.0 \%$ of the annual output value. The average annual growth of R \& D investment reached $9.7 \%$.

\section{3) New products are growing rapidly}

In 2016, a total of 253 new products and 190 new devices and technologies were developed by 29 small and mediumsized technological innovative enterprises. 27 kinds of scientific and technological achievements are absorbed. A total of 115 patents (including 25 invention patents and 90 utility new patents), 95 patents (including 4 invention patents and 91 utility new patents), 50 kinds of other intellectual property rights, such as design, software copyright, etc.

4) The level of scientific research is constantly improving.

In the past three years, 29 small and medium-sized technological innovative enterprises have won 12 scientific and technological awards, including 11 at the municipal level and 1 at the provincial level.

\section{COUNTERMEASURES AND SUGGESTIONS FOR IMPROVING THE INNOVATIVE ABILITY OF TECHNOLOGICAL INNOVATION ORIENTED SMES}

\section{A. Strengthening the construction of collaborative innovation and improving the efficiency of scientific and technological innovation}

1) Strengthen the leading role of enterprises in innovation

Establish a high-level, normalized enterprise technological innovation dialogue and consultation system, and give full play to the important role of enterprises and entrepreneurs in innovation decision-making. More enterprises are involved in research and development of technological innovation plans, plans, policies and standards. We will carry out pilot projects for innovative transformation of leading enterprises and explore new mechanisms for government support for technological innovation, management innovation and business model innovation. In accordance with the principle of "enterprise autonomy, market operation, policy support", we will vigorously develop enterprise research institutes, academician expert workstations and post-doctoral workstations, and award enterprises R\&D centers and technical centers recognized at the national, provincial and municipal levels respectively. By 2020, more than 100 research institutes should be set up, and more than 10 post doctoral stations should be received. 


\section{2) Strengthen the construction of collaborative innovation} organization

We will actively promote cooperation between enterprises, universities and scientific research institutes, with property rights as the link and projects as the backing, and form a cooperative innovation mechanism with complementary advantages, common development, benefit sharing and risk sharing. Supporting universities and scientific research institutes to convert non-profit state-owned assets into profitmaking state-owned assets for R\&D and industrialization of scientific and technological achievements. The amount of municipal scientific and technological Funds Supporting universities and research institutes in Jinan should be linked with the corresponding $\mathrm{R} \& \mathrm{D}$ expenditure. By purchasing services, the government encourages universities and research institutes to adopt a market-oriented approach, open up various types of scientific and technological resources to enterprises, and provide testing, testing, standards and other services for enterprises. We will support small and medium-sized scientific and technological enterprises, scientific research institutes, colleges and universities, and large enterprises to jointly establish technological research and development institutions and strategic alliances for industrial technological innovation, jointly carry out research, development, popularization and application of key industrial technologies, and share scientific and technological innovation achievements.

\section{B. Implementing "innovation +" action plan to cultivate new economic growth points}

1) Implement "innovation + entrepreneurship" plan.

Through scientific and technological plans, policy services and other means, strive to add more than 100 new and hightech enterprises, science and technology-based SMEs every year. Encourage the scientific and technological personnel of universities and scientific research institutes to set up small and medium-sized scientific and technological enterprises, guide college graduates to innovate in entrepreneurship, and actively attract high-level talents from overseas to set up businesses in Jin. We should reduce the threshold for starting businesses and simplify the procedures for applying for registration by scientific and technological enterprises. We encourage and support the return of businessmen from outside Jinzhou to the establishment of scientific and technological enterprises, innovative enterprises and $\mathrm{R} \& \mathrm{D}$ centers. Scientists and technicians are encouraged to invest in enterprises with independent scientific and technological achievements such as trademarks, patents and non-patented technologies. The intellectual property rights acquired by the job-related inventions of universities and scientific research institutions may be used and implemented by the qualified inventors themselves. If a venture capital enterprise invests in an unlisted small and medium-sized high-tech enterprise by means of equity investment, it shall be given certain income tax preferences. Jinzhou's top 100 enterprises in science and technology innovation will be selected.

\section{2) Implement the plan of "innovation + emerging industries"}

Integrating various special funds for industrial development organizing and implementing major industrial science and technology projects, implementing the "trinity" reform measures of scientific and technological projects, research and development institutions and innovative talents, and actively promoting petrochemical and fine chemicals, new titanium and metal materials, automobiles and spare parts, new photovoltaic energy and electronic information, biomedical and health products Industry and other strategic emerging industries. In the economic and Technological Development zones, high-tech zones, University Science and technology parks and other high-end functional zones, land should be allocated in a certain proportion for the development of strategic emerging industries, high-tech industries. We will actively cultivate and develop science and technology services such as R\&D and design, intellectual property rights, inspection and testing, transformation of scientific and technological achievements, information technology and biotechnology services, and promote the integration and development of new cultural industries and traditional industries.

\section{Improve the incentive mechanism and dymatic role of innovative talents}

1) Increase the motivation of scientific and technological personnel

Strengthen respect for knowledge, respect for innovation, fully reflect the distribution of intellectual labor value orientation, so that scientific and technological personnel in innovative activities get a reasonable return. The income from the transfer of job-related inventions in universities and scientific research institutions shall be reasonably distributed among the important contributors and their affiliated units. The proportion of the income from the transfer of job-related inventions to the important contributors and teams used for rewarding scientific research leaders and backbone technicians may be raised from not less than $20 \%$ to not less than $50 \%$. The rewards given by state-owned enterprises and institutions to persons who have completed their job inventions, those who have made important contributions to the transformation of scientific and technological achievements and their teams shall be included in the total unit wages of the current year, and shall not be taken as the base of the total wages. All kinds of enterprises are encouraged to mobilize the enthusiasm of scientific researchers for innovation by means of stock rights, options and dividends. For the enterprises that are invested in scientific and technological achievements by institutions of higher learning, scientific research institutes and other institutions, the restrictions on the establishment period and profit level of the enterprises shall be relaxed. When scientific researchers of high-tech enterprises and small and mediumsized scientific and technological enterprises obtain equity incentive income through the transformation of scientific and technological achievements, they shall, in principle, pay individual income tax in stages within five years. 
2) Establish a two-way flow mechanism for scientific research talents

We should improve the salary and post management system for scientific researchers, remove the institutional and institutional barriers to the flow of talents, and promote the rational flow of scientific researchers between institutions and enterprises. The qualified scientific research personnel of the scientific research institutes may, with the approval of their units, bring scientific research projects and achievements and retain basic treatment to the enterprises to carry out innovative work or establish enterprises. Institutions of higher learning and scientific research institutes are encouraged to set up a certain proportion of mobile posts to attract entrepreneurs with innovative and practical experience and scientific and technological personnel of enterprises to take part-time jobs. The pilot will regard the enterprise experience as a necessary condition for new engineering teachers in Colleges and universities. We should speed up the reform of the social security system, improve the policy of transferring and continuing social security relations when scientific researchers move between enterprises and institutions, and promote the two-way free flow of talents.

\section{Strengthen the function of financial innovation and} establish a pluralistic technology investment and financing system

\section{1) Expand the scale of innovation investment}

We should give full play to the role of financial innovation in promoting technological innovation, foster and strengthen venture capital and venture capital, improve the flexibility and convenience of credit support innovation, and form a good situation in which all kinds of financial instruments cooperate to support innovation and development. We should seize the opportunity for Jinzhou to build a regional financial center in Western Liaoning Province, strive to carry out the pilot project of share transfer system for small and medium-sized enterprises, and actively guide private capital to invest in scientific and technological innovation and talent entrepreneurship. We will set up science and technology financial service platforms such as science and technology financial service center, science and technology credit risk pool fund, venture capital guidance fund, science and Technology Venture Capital Limited company, Jinzhou Intellectual Property Trading Co., Ltd. to support the establishment of science and technology banks (branches) and pilot projects of science and technology loan guarantee insurance to guide and support financing. Guarantee companies develop new products of science and technology guarantee, and accelerate the formation of a diversified, multi-level, multi-channel investment and financing system for scientific and technological innovation. We will establish and improve platforms for technology trading, cultural and financial property rights trading, technology property rights quotation system and venture capital alliances, and support technologybased enterprises to enter multi-level capital markets, so as to realize the docking of venture capital, non-governmental capital and science and technology projects.
2) Innovate the way of financial investment in science and technology

The growth rate of financial investment in science and technology should be higher than that of the regular revenue of the primary finance. During the 13th Five-Year Plan period, the proportion of municipal expenditure on science and technology amounted to more than $1.4 \%$ of the current financial expenditure at the municipal level, and the proportion of other counties (cities) amounted to more than 1.3 respectively. Municipal and county (city, district) financial scientific and technological funds should focus on the construction of scientific and technological innovation service platform, enterprise technological innovation and achievement industrialization projects. We should give full play to the leverage role of financial funds for science and technology, and innovate the use of various forms of financial investment in science and technology, such as awards and subsidies, loan discounts, venture capital guidance, public-private joint ventures, to improve the total amount of investment in science and technology and the performance of the use of financial funds throughout the society. Integration of financial science and technology funds initiated the establishment of venture capital funds, equity investment funds, as seed funds to attract private capital investment in high-tech enterprises and technology-based enterprises.

3) Broaden the indirect financing channels for technological innovation

Taking the construction of Liaoxi regional financial center as an opportunity, financial institutions should be guided to explore financing services combining equity and creditor's rights for enterprises'innovative activities, and to realize investment and loan linkage with venture capital and equity investment institutions. We should steadily develop private banks and Internet finance, establish a regulatory system suitable for them, and support the innovation of financial products for SMEs. We should establish a market based risk compensation mechanism for intellectual property pledge financing and simplify the process of intellectual property pledge financing. We should accelerate the development of science and technology insurance and promote the pilot project of patent insurance.

\section{CONCLUSION}

To further cultivate and strengthen the scientific and technological SMEs, local governments have to take good use of the advantage of institutes, such as strengthening the construction of collaborative innovation and improving the efficiency of scientific and technological innovation, implementing the "innovation + " action plan to cultivate new economic growth points, improving the incentive mechanism of innovative talents and the dynamic role of innovative talents, strengthening the function of financial innovation and establish a pluralistic technology investment and financing system.

Therefore, small and medium-sized science and technology enterprises will enhance the ability of scientific and technological innovation, support sustainable economic development, and expand social employment. 


\section{REFERENCE}

[1] [Shleifer A, Vishny R W. The Grabbing Hand: Government Pathologies and Their Cures [J]. Americmi Economic Association Paper \& Proceeding, 2000, 87(02):354-358.

[2] Wu W3 Wu C, Zhou C, et al. Political connections, tax benefits and firm performance: Evidence from China [J]. Journal of Accounting \& Public Policy, 2012, 31(03):277-300.

[3] Li Hong bin, Ling sheng Meng, Qian Wang, Li-An Zhou, 2005, tfiPolitieal Connections and Firm Perform 姐 ce: Evidence from Chinese Private Firms' CIG Working Paper Series. 